\title{
Research and Practice on Innovation and Entrepreneurship Education System in Vocational Colleges
}

\author{
Xiaojiang Chen \\ Jiangsu Agri-animal Husbandry Vocational College \\ Taizhou City, Jiangsu Province, China \\ cq_cxj@126.com
}

\author{
Liangwei Xiong \\ Jiangsu Agri-animal Husbandry Vocational College \\ Taizhou City, Jiangsu Province, China \\ fanjing20152016@126.com
}

\author{
Qixiang Sun* \\ Jiangsu Agri-animal Husbandry Vocational College \\ Taizhou City, Jiangsu Province, China \\ dwddwd98@126.com
}

\begin{abstract}
In order to improve the quality of personnel training, promote the close integration of education and economic development. Aiming at the existing problems of innovation and entrepreneurship education occupation colleges, comparative literature over the years, from the talent training scheme, curriculum system, educational mode, platform construction, teachers construction, system construction, six aspects of research. The results showed that the system of innovation and entrepreneurship education into six aspects of cultivating talents, enhance students' innovation and entrepreneurship awareness and innovation ability, the number of students entrepreneurship practice increased significantly, significantly improve the quality of personnel training.
\end{abstract}

Keywords-Innovation and Entrepreneurship; Vocational Colleges; Education; Platform Construction

\section{INTRODUCTION}

"The general office of the State Council on deepening the reform of Higher Education Implementation Opinions" 2015 Document No. 36, pointed out that deepening the innovation and entrepreneurship education reform, is the implementation of science and education and talent strategy and innovation driven development strategy, promote the inherent requirement of economic quality and efficiency upgrades, is to deepen the comprehensive reform of higher education, improve the personnel training important measure of quality, promote higher education and economic and social development closely. In recent years, the innovation and entrepreneurship education of vocational colleges has been strengthened [1], and positive progress has been made [2]. It has played an important role in realizing higher quality entrepreneurial employment and promoting the economic and social development of vocational education [3]. But there is also a lag part of school innovation and entrepreneurship education concept [4], out of touch with the personnel training and professional education [5], teachers to carry out creative education awareness and ability [6], practice platform construction and guidance is not in place [7], the entrepreneurship education system innovation to be perfect [8].

\section{PERFECT TO IMPROVE THE ABILITY OF INNOVATION AND ENTREPRENEURSHIP-ORIENTED TRAINING PROGRAMS}

\section{A. Strengthen the central position of talent training}

Fully implement the party's education policy, implement the fundamental task of morality education and professional education, and promote the integration of professional education and innovation and entrepreneurship education. Through a similar discipline or professional basic courses, curriculum setting up cross disciplines, to establish a new mechanism of cross department, interdisciplinary and multidisciplinary cross to cultivate innovative talents, combining the all-round development of students with the development of individual character, it can promote the transformation of talent training from a single discipline type to a multidisciplinary one, and a distinctive idea of innovation and entrepreneurship education.

\section{B. Highlights the requirements of innovation and entrepreneurship education}

According to the relevant professional teaching quality of national standards and industry standards, revised professional quality standards. The proportion of practice and training should be no less than $50 \%$, and the time and mode of practice training should be flexibly arranged.

\section{ESTABLISH A NEW MECHANISM FOR INNOVATION AND ENTREPRENEURSHIP EDUCATION}

A. Work closely with local governments, industries, enterprises and other institutions of higher learning

Effective integration of government and social resources, and strengthen the University and government departments, industry, enterprises and social institutions docking. The 
establishment of modern animal husbandry China vocational education group, entrepreneurship education in Colleges and universities in Jiangsu to join the alliance of innovation, the innovation and entrepreneurship education to carry out special cooperation with other domestic and foreign universities and research institutions, and actively carry out the Sino foreign cooperation, relying on the "people enriching project" will be innovative achievements in the practice. We should actively join the organizations and platforms that are jointly participated by universities, governments, enterprises and society, and establish a sound interaction mechanism of innovation, entrepreneurship and education.

\section{B. Promotes seamless docking within vocational colleges}

To explore the demand oriented discipline, professional structure and entrepreneurial employment oriented personnel training type, structure adjustment mechanism. Set up a comprehensive coordination institution for innovation and entrepreneurship, which is responsible for promoting the reform of innovation and entrepreneurship education. The establishment of educational administration department as the leading and innovation center, two level departments as the main body of the innovative teaching system, build innovation and entrepreneurship training and practice system of educational administration, school work, collaborative departments and faculties of the Communist Youth League and other functions. Improve the innovation and entrepreneurship center, university entrepreneurship Park, University Science Park and other collaborative innovation, entrepreneurship incubation system.

\section{INNOVATION AND ENTREPRENEURSHIP EDUCATION CURRICULUM SYSTEM INTEGRATING SOUND AND PROFESSIONAL TRAINING}

\section{A. The construction of entrepreneurship and innovation education curriculum system}

Opened entrepreneurship education general education courses, professional development and the related basic curriculum innovation and entrepreneurship education, in the professional course in the innovation of idea, thought and spirit of entrepreneurship education principles and methods, the construction of elective compulsory, theory and practice, out of class, online and offline, the combination of school, entrepreneurship education curriculum innovation system combining with professional training.

\section{B. Integration of innovative entrepreneurship education curriculum resources}

In accordance with the basic rules and characteristics of innovation and entrepreneurship education, we should tap and enrich the educational resources for innovation and Entrepreneurship of all kinds of specialized courses. Promote the innovation of entrepreneurship education curriculum information, establish innovation and entrepreneurship education curriculum resource sharing platform, the implementation of online open courses and second classroom credit accreditation system. Actively invite innovation and entrepreneurship education experts, well-known entrepreneurs into the classroom, to promote high-level innovation and entrepreneurship lectures, high grade innovative entrepreneurial activities into the curriculum. Strengthen cooperation between schools and publishing institutions, set up complementary innovation and entrepreneurship education curriculum construction team, and further strengthen innovation and entrepreneurship education, excellent courses and teaching materials construction.

\section{CONSTRUCTING AN EDUCATIONAL MODE SUITED TO THE IDEA OF INNOVATION AND ENTREPRENEURSHIP EDUCATION}

\section{A. New model of education}

\section{1) Reform teaching methods}

To promote research teaching, we should extensively carry out heuristic, discussion, participatory and project-based teaching, and expand the scope of small class teaching, Support the students to study learning and innovation and entrepreneurship program simulation experiment, the real academic activities, frontier development, the latest research results and practical experience of innovation into classroom teaching, the innovation concepts, principles and methods into the teaching of professional courses. Play the role of innovation, entrepreneurship, tutor "pass, help and bring", and guide students to participate in innovation and entrepreneurship practice with "master apprentice". Using modern educational technology and taking many kinds of teaching methods, such as "turn over class" and "mixed teaching", students' critical and creative thinking should be trained to stimulate students' creativity and entrepreneurship.

\section{2) Improving students' academic evaluation methods}

The reform of examination contents and methods, focusing on knowledge innovation ability to analyze and solve the problems by using test students, explore flexible open assessment methods, promote the process of assessment, assessment results to the knowledge ability assessment to assessment, performance assessment methods to a variety of change. Set up reasonable credit for innovation and entrepreneurship, set up credits for professional innovation courses and practice of innovation and entrepreneurship, and expand the credit accumulation and transformation system. The implementation of flexible educational system, broaden students age, allowing adjustment of academic process, retain the school of innovation and entrepreneurship. Students who have made remarkable achievements in innovation and entrepreneurship and who have been determined to meet the requirements of degree granting may be awarded corresponding degrees

\section{B. To carry out various forms of innovative business practice}

\section{1) Build a platform to share innovation and entrepreneurship practice}

Strengthen professional laboratory, virtual simulation laboratory, innovation and entrepreneurship practice education center construction, and actively build student entrepreneurship Park, entrepreneurial Incubation Park, science and technology 
parks, innovation and entrepreneurship practice platform. Promote innovation, entrepreneurship, theoretical teaching, discipline competition, project practice and integration of base construction. Promote innovation, entrepreneurship, theoretical teaching, discipline competition, project practice and integration of base construction.

\section{2) Improve the implementation system of innovation and entrepreneurship training program}

In depth implementation of the innovative training program for college students and a new round of college students lead the business plan, the formation of national, provincial, school, hospital (Department) four levels of innovation and entrepreneurship training program implementation system. We will organize and publicize training programs for innovative and pioneering students, and strive to make every college student participate in at least one training program for college students' innovation and entrepreneurship. Relying on the Jiangsu province undergraduate innovative training program platform, the completion of innovation and entrepreneurship project display, results transformation, school enterprise docking. The establishment of College Students' innovation and entrepreneurship training program of the network management platform, strengthen the management of the implementation process, for college students to keep abreast of policy and industry information, learning accumulated industry experience, find partners and venture investors to create favorable conditions.

\section{3) Actively organize students to participate in various types of innovation and entrepreneurship competition}

Innovation and entrepreneurship competition, for all students actively organize the occupation skills contest and all kinds of scientific and technological innovation, creative design, business plan and project contest preliminaries, the school issued the relevant incentive measures to encourage students to participate in the "Internet plus" College Students' innovation and entrepreneurship competition, "Challenge Cup" University student extracurricular activities, organized independently in accordance with all kinds of innovation and entrepreneurship competition discipline characteristics. Introduce relevant documents, improve the competition program and curriculum mutual recognition, credit exchange methods, the innovation and entrepreneurship competition into the curriculum system of practical teaching, so as to promote the teaching of competition and promote learning by competition

\section{Promotes teachers' ability and level of innovation, entrepreneurship, education and teaching}

\section{1) Selection of talent pool for innovation and entrepreneurship, and strengthening mentor team building}

According to the main, full-time special combination of the principle of optimization of college teachers' troop structure, encourage the university to hire outstanding talents in various industries as a professional course, innovation and entrepreneurship classes or teachers, attract entrepreneurs and technical personnel to the school part-time experience of innovation and entrepreneurship. We will improve the education and training system for teachers' innovation and entrepreneurship, build a platform for teachers' innovation and entrepreneurship education and training, and bring up a team of teachers who are able to integrate innovation and entrepreneurship education with quality education and professional education.

\section{2) Improve the relevant teachers' professional and technical posts evaluation standards}

The innovation and entrepreneurship education into professional and technical titles and standard performance evaluation index system, to support the transfer of foreign teachers, cooperative transformation, the price of shares, entrepreneurship and other forms of industrialization of scientific and technological achievements, to encourage teachers to lead students to innovation and entrepreneurship. Establish and improve the innovation and entrepreneurship education of professional teachers, full-time teachers to enterprises and township post training system, encourage professional teachers to participate in social innovation and entrepreneurship practice, guide professional teachers to carry out the theory and case study on innovation and entrepreneurship education

\section{Pay attention to the encouragement and support of} teachers and students' innovation, entrepreneurship and their education and teaching

\section{1) All teachers should be encouraged to carry out innovation and entrepreneurship education}

Regular selection of innovative entrepreneurship excellent teaching team, innovation and entrepreneurship teacher, outstanding young instructors, at the same time, innovation, entrepreneurship, teaching achievement as a result of higher education teaching awards recognition important content.

\section{2) Encouraging college students to innovate and start an undertaking}

Funded students to carry out innovation and scientific research work, the establishment of innovative entrepreneurship scholarships, and in the existing relevant assessment of the first assessment project to take a certain proportion of recognition for innovation and entrepreneurship outstanding performance of the students. To explore the students to carry out innovation and entrepreneurship training, published papers, patents and self-entrepreneurship, etc., converted to credit, priority support for students involved in innovation and entrepreneurship into related professional learning.

\section{E. Strengthen the organization of innovation and entrepreneurship education reform and support services}

\section{1) Implement the main responsibility}

Deepening the innovation and entrepreneurship education reform as the strategic task of "training what people and how to train people" is included in the important agenda of the comprehensive reform of schools, the leading group of 
innovation and entrepreneurship education was set up by the principal comrades in charge of the team, the comrades in charge, the deputy leaders, the educational administration and other relevant departments. The elaboration of reform and innovation and entrepreneurship education implementation plan, and implementation plan of education administrative department and the provincial authorities for the record, to the public for the record. Experts from various industries, entrepreneurs and financial circles are invited to set up an Advisory Committee on innovation and entrepreneurship education, and provide decision-making consultation and guidance services.

\section{2) Co-ordinate all kinds of funds to support college students innovation and entrepreneurship}

Multi-channel arrangements for funding, innovation and entrepreneurship education demonstration school, entrepreneurship demonstration base, innovation and entrepreneurship education practice center construction, support the construction of curriculum materials, academic competition, innovation and entrepreneurship training program, the implementation of entrepreneurship incubator project work, innovation and entrepreneurship education and the establishment of stable growth mechanism. Actively publicize the government's policies on promoting entrepreneurship, employment, support and preferential policies to reduce the threshold and cost of College Students' innovation and entrepreneurship. Initiative to help students strive for all kinds of social organizations, public welfare organizations, enterprises and institutions and individuals established risk fund for college students, in a variety of ways to provide financial support for self-employment College students.

\section{CONCLUSION}

The author's Institute, adhere to the "education oriented", for all students, the innovation and entrepreneurship education into the personnel training system, in order to improve the quality of personnel training as the core, focusing on innovative personnel training mechanism, actively promote the teaching and scientific research and practice of cooperative education curriculum system and education mode reform, cultivating the weak links of various forms of breakthrough talent, entrepreneurial practice, enhance students' innovative spirit and entrepreneurial consciousness and innovation ability. Increase supervision and publicity to guide efforts to strengthen teachers, improve teachers' teaching ability and level of innovation and entrepreneurship education, the introduction of various incentives and support services, to significantly improve the quality of personnel training, students' innovation and entrepreneurship awareness and innovation ability significantly enhanced entrepreneurship practice students increased significantly, the innovation and Entrepreneurship Education reform at the forefront of the country, In recent years it has been appraised as the top 50 universities of national innovation and entrepreneurship, and the top 30 universities of national employment competitiveness.

\section{ACKNOWLEDGMENT}

The authors are thankful to Jiangsu University Philosophy and Social Science Research Fund Project support (Grant NO: 2015SJB863). Research on Teaching Reform of Higher Education in Jiangsu Province for financial support (Grant NO 2015JSJG592). Jiangsu Agri-animal Husbandry Vocational College, the 335 reform of teaching and research fund project support (Grant NO:2014020605)

\section{REFERENCES}

[1] Gong B, Lai X, Zhang J, et al. Reconstruction of Innovation and Entrepreneurship Education System in Application- oriented Universities [J]. Journal of Jixi University, 2016.

[2] Xie S, Wu M. A Brief Analysis on the Construction of Innovation and Entrepreneurship Education System in Applied Undergraduate Universities of Nanjing [J]. Science Education Article Collects, 2016...

[3] Zhang Z. Constructing the practical teaching system of innovation and entrepreneurship education for engineering college students[C]// International Conference on Computer Science \& Education. IEEE, 2014:877-882.

[4] R. Radharamanan, Jeng-Nan Juang. Innovation and entrepreneurship in engineering education at MUSE [J]. Journal of the Chinese Institute of Engineers, 2012, 35(1):25-36..

[5] Yonezawa L S A. Innovation and entrepreneurship: trials of Japanese universities [J]. Globalisation Societies \& Education, 2012, 10(3):367385

[6] Wilson C, Lennox P. Education for innovation: exploring the place of creativity, innovation and entrepreneurship in Higher Education [J]. Wilson Chris, 2012

[7] Radharamanan R, Juang J N. Innovation and Entrepreneurship Education in Engineering [M]// Proceedings of the 2nd Internationa Conference on Intelligent Technologies and Engineering Systems (ICITES2013). Springer International Publishing, 2014:1281-1290

[8] Chen G. Study on the Education Plan of the Creativity, Innovation and Entrepreneurship Ability in University Students [M]// Computing and Intelligent Systems. 2011:305-311. 